\title{
РАЗДЕЛІІ. МЕНЕДЖМЕНТ
}

\section{Izmailova M., Vaschenko R. \\ Corporate innovative systems in the conditions of digital economy: the essence and features of their implementation in the Russian Federation}

Financial University under the Government of the Russian Federation

(Russia, Moscow)

doi:10.18411/spc-08-04-2018-23

idsp: 000001:spc-08-04-2018-23

The changes happening now in the global economy and influencing the functioning of each subject of economic relations demand a certain strategic approach from our state and private sector. The necessity to form the most effective system of innovation management in a corporate sector as an organized set of mechanisms, methods and procedures, has reached its historical maximum.

The special complexity of this period is caused by the process of innovative transformations in the Russian Federation. The digital economy is a dual phenomenon which significantly complicates the efficiency of administrative influence and at the same time forms a basis of future transformations almost in all areas of social and economic sector.

According to the data provided the European Commission digital economy is estimated at 3,2 trillion euro in the group of countries of "Group of Twenty" and makes about $8 \%$ of GDP. The global institute of McKinsey noted in the research conducted in May, 2011 that the Internet is the major element of economic progress as it provides a considerable part of economic growth: the Internet contribution to GDP of the developed countries was $10 \%$ in total during the 15-year period of 1995-2009s and during the last 5 years (2011-2016) it reached $21 \%$. The development of digital economy is closely connected with the development of Internet network access, but such "communication channel" has itself no value if people are not able to learn to use its technologies effectively [7].

The digital economy creates new assets like data, forms both new sales markets of production and the products and also significantly influences the commercialization of information technologies in the territory of the Russian Federation. Answering the challenges of the present time, the infrastructure of science and innovations in the form of various institutes of development, science and technology parks and business incubators has already been created in Russia, but still it is too early to speak about any essential results of this work [2].

The main objective all the companies which are seeking for development face now is the creation of a corporate system which will be able to quickly react to present challenges, to contribute to social and economic growth and stable development of commercial potential. According to main aims of this "mechanism" an effectively built corporate innovative system can help to achieve this effect.

A corporate innovative system (an innovative system of an enterprise) represents a set of the major factors making an impact on development, distribution and usage of innovations, an efficiency increase in an innovative process in a company and also the interrelation between these factors [4]. In other words, a CIS is a set of various elements of a corporate structure in the field of innovations which are aimed at providing the realization of the main objective of a company with the best result.

The main objectives of a corporate innovative system are providing the growth of different indicators of a company, competitiveness of its production (or services) and profitability via the mechanisms of innovative transformations.

The achievement of above-listed goals is possible in the conditions of finding the solution to the following tasks: introduction of new administrative and managerial mechanisms or modernization of outdated ones; creation of corporate culture in a company; 
development of labor productivity; formation and usage of innovative methods on reducing costs of a company; an increase in a social appeal of goods or provided services in the Internet network taking into account current trends; improvement of productive quality by using modern technologies.

As the practice shows, the main difficulties in the field of innovations large modern Russian companies have to face are connected with their impossibility to carry out the process of development or introduction of innovations independently. As a result, companies have to work with an outdated technological base. A very short-term effect and a weak result which has no long-term prospective is a consequence.

According to the data of a quantitative research which is published in the joint National report of Managers' Association, the Russian venture company and Institute of management of innovations of National Research University Higher School of Economics, large companies prefer to upgrade and improve the development and deployment of new products: the ratio is $87 \%$ (improvement of already existing products and technologies) to $78 \%$ (creation of essentially new products). Small companies have a cardinally opposite situation: the ratio is 54 against $86 \%$ that confirms a hypothesis that at the present time large companies are afraid to risk with the purpose to avoid extra risks and to hold the markets they have already been in, but at the same time it is a chance for small and medium business to become a pioneer in this sphere and to show themselves [5].

It goes without saying that some large and financially wealthy companies which possess all the necessary assets are still able to afford full usage of innovations for the purpose of increasing the efficiency and effectiveness of their activity. PJSC Sberbank can become an example of such a company. According to the position of the administration of PJSC Sberbank which was proclaimed by the head of the Center of technological innovations of Sberbank E. Frolovicheva during the forum "FinNext-2016" an innovation is not only a product or service inside the company: "An innovation is an organization itself, skills and technologies. That is a set of all the things which have to be in every organization" [6].

At the present time Sberbank is involved in the active introduction of new technologies into its operation (cloud computing, open interfaces, mobile and wearabletechnologies, etc.) that is a strong confirmation of successful execution of "The development strategy of Sberbank for 2014-2018". According to the development strategy, introduction of information systems and infrastructures were one of the most important and difficult stages of bank transformations, but finally they managed to gain the necessary effect: centralization and unification of the automated systems; a level increase of automatization of bank processes and as a result improvement of customer service quality; using a large number of new systems (control systems of interaction with clients, risk management or client information) in their work; creation of remote and digital channels for interaction with clients. At the same time the directions which failed to succeed are also outlined: providing reliability and uninterrupted operation of IT system functioning, efficiency of IT processes and cost management in the sphere of information technologies.

Full-time employment in the financial area (optimization of expenses), staff interaction, an increase of efficiency of the system of purchases as well as transformation of administrative processes are conducted in Sberbank except information technologies which is also reflected in the development strategy [8].

The mechanism of constant improvement of client experience and an increase in overall performance of the company is formed as a result of efficient work of Sberbank production system (constructed on modernization of all the processes, a managerial system and corporate culture) that is a basis of competitive advantages of Sberbank for sure.

Thus, it is possible to speak about the fact that PJSC Sberbank has reached its main objectives which are necessary for forming an efficient corporate innovative system: modern approaches to administrative management; work with the personnel in the field of corporate culture; motivation for the development of labor productivity; reducing costs and an increase in a social appeal of the provided services and its brand as well as the improvement of production quality by the maximum usage of modern technologies. 
It goes without saying that Sberbank really lacks both calculations of financial and non-financial indicators for the entire period containing the figures "before" and "after" to make a full-fledged conclusion concerning the efficiency of the conducted transformations, but now it is still too early to speak about it as bank modernization has not been completely finished and there is no final data for analyzing.

At the same time, it is possible to draw a conclusion about the prospects of using this corporate innovative system for modern Russian companies which has already produced some results among large representatives of the corporate sector. It is important to remember that availability of a strong resource base of a steadily functioning enterprise (while carrying out the reforms) is an indispensable condition for the attempt of organizing and carrying out innovative transformations in the course of the formation of digital economy and its impact on the corporate sector. However, nowadays there are positive prospects for development of the commercial sector and it would be a crime not to use them taking into consideration a quickly developing activity of the Government of the Russian Federation in this field and the state support of the sphere of research and development in Russia.

$$
* * *
$$

1. Федеральный закон от 23.08.1996 N 127-ФЗ (ред. от 23.05.2016) "О науке и государственной научнотехнической политике" (с изм. и доп., вступ. в силу с 01.01.2017) [Электронный ресурс] - Режим доступа: http://www.consultant.ru/document/cons_doc_LAW_11507/ (дата обращения: 15.11.2017);

2. Распоряжение Правительства Российской Федерации от 28 июля 2017 года №1632-р «Об утверждении программы «Цифровая экономика Российской Федерации» [Электронный ресурс] Режим доступа: http://www.consultant.ru/document/cons_doc_LAW_221756/ (дата обращения: 15.11.2017);

3. Ермакова, Е.А. Механизмы формирования и функционирования корпоративной инновационной системы : автореферат дис. ... кандидата экономических наук : 08.00.05 / Ермакова Елена Александровна - Нижний Новгород, 2012;

4. Курятников, А.Б., Линдер Н.В. Особенности построения корпоративных инновационных систем холдингов. Управление инновационными процессами холдинга / А.Б. Курятников, Н.В. Линдер //Стратегии бизнеса. - 2015. - № 8;

5. Управление исследованиями и разработками в российских компаниях. Национальный доклад. М.: Ассоциация Менеджеров, 2011;

6. 5 мифов о технологических инновациях в Сбербанке [Электронный ресурс] - Режим доступа: http://futurebanking.ru/post/3209 (дата обращения: 20.11.2017);

7. Отчет McKinsey «Цифровая Россия: новая реальность» [Электронный ресурс] - Режим доступа: https://corpshark.ru/p/opublikovan-otchet-mckinsey-tsifrovaya-rossiya-novaya-realnost/ (дата обращения: 20.11.2017);

8. Стратегия развития Сбербанка на период 2014-2018 [Электронный ресурс] - Режим доступа: http://www.sberbank.ru/ru/about/today/strategy_2018 (дата обращения: 22.11.2017).

\section{Лютер Е.В., Ворожейкин А.С. \\ Метод оценки финансовой устойчивости предприятия-исполнителя государственного контракта}

ФГБОУ ВО «Московский авиационный институт (Наџиональный исследовательский университет)»

(Россия, Москва)

doi:10.18411/spc-08-04-2018-24

idsp: 000001:spc-08-04-2018-24

\section{Аннотация}

В настоящей статье предложен оригинальный авторский метод оценки финансовой устойчивости предприятий-исполнителей государственного оборонного заказа. Метод учитывает финансовые и экономические показатели деятельности предприятия и может использоваться для выбора исполнителя государственного контракта. Предлагаемый комплексный показатель оценки финансово-экономической устойчивости так же может быть использован государственным заказчиком на этапе 